\title{
Restructuring Large Scale State Enterprises at the End of the Russian Supply Chain:The Challenge for Technical Assistance and Investment in the Central Asian Republics*
}

\author{
John S Henley / George B Assaf ${ }^{* *}$
}

There has been much debate about the speed and sequencing of policy reform necessary to bring about restructuring of large state enterprises in transition economies. The new republics of Central Asia have had little choice: the collapse of the former Soviet Union in 1991 precipitated a crisis situation, as a result of which enterprise restructuring became urgent and vital to the survival of national economies and civil society. Seven short case studies of enterprises from Azerbaijan, Kazakstan, the Kyrgyz Republic and Uzbekistan are presented to illustrate some of the challenges facing technical assistance efforts and investment in the industrial sector of Central Asia.

Es ist viel darüber diskutiert worden, welche Schnelligkeit und Abfolge politischer Reformen für die Restrukturierung großer staatseigener Betriebe in den Transformationsländern notwendig ist. Die neuen zentralasiatischen Republiken hatten kaum eine Wahl. Der Zusammenbruch der früheren Sowjetunion 1991 verursachte eine Kriesensituation, in der die Restrukturierung für das Überleben der nationalen Wirtschaft und der Gesellschaft dringend notwendig war. Es werden 7 Fallstudien von Unternehmen in Aserbaidshan, Kasachstan, der Kirgisischen Republik und Usbekistan vorgestellt. Diese sollen einige Herausforderungen für die technische Unterstützung, den Einsatz und die Investitionstätigkeit im industriellen Sektor Zentralasiens illustrieren.

Manuscript received: 18.11.96, accepted: 22.1.97

** John S Henley, born 1943, Professor of International Management at The University of Edinburgh Management School. Major areas of research interest: enterprise restructuring, commercialisation and privatisation in the transition economies and the internationalisation of retailing and distribution in central Europe.

Mail address: University of Edinburgh, Department of Business Studies, 50 George Square, Edinburgh EH 8 9JY

Email: Lorraine.edgar@ed.ac.uk

George B Assaf, born 1953, Global Report Team, Studies and Research Branch, UNIDO. Major areas of research interest: Globalisation, the stimulation of investment in manufacturing industry and the role of technical assistance in encouraging industrial growth in developing countries. 


\section{Introduction $^{*}$}

The process of dissolution of the former Soviet Union (FSU) and the progression to independence of the Newly Independent States (NIS) of Central Asia has been punctuated by a series of trade shocks to the fledgling economies of unprecedented severity even by the standards of eastern Europe. The major shocks occurred in 1991 with the collapse of the USSR, in 1992 with the departure of the Ukraine from the rouble zone, in 1993 with the complete collapse of the rouble zone, and in 1994 as a result of the massive output decline in the Russian Federation and the NIS countries generally (the main source of inputs, raw materials and spare parts and markets for the countries of the region). These trade shocks have had major repercussions for large state enterprises many of which were hitherto tightly integrated through the all-Union central planning mechanism with suppliers of raw materials, intermediate inputs and downstream end-users. Suppliers and customers were often deliberately geographically dispersed throughout the USSR by the central planners.

There has been considerable debate about the speed and sequence of policy reforms necessary to bring about the restructuring, commercialisation and privatisation of large state enterprises in Central and Eastern Europe (Rana 1995; Amsden/ Kochanowicz/ Taylor 1994; Sachs/ Woo 1994; Naughton 1994). However, in the case of Central Asia, it is pointless to debate whether governments should choose a gradual reform programme: economic and political shock was imposed on the region by the sudden and unexpected collapse of the former Soviet Union. In the wake of this collapse, there has been little disagreement about the need to support the restructuring process with specific measures and assistance. There is little choice, unless, of course, the intention is to allow enterprises to collapse into bankruptcy. Action has to be taken, for without restructuring, most enterprises in the region are not viable, yet potentially many are salvageable with carefully targeted assistance, debt restructuring, and relatively modest new investment. Later in this paper we provide short case studies of the problems facing a variety of large state enterprises operating in Central Asia in order to illustrate the magnitude of the challenges facing restructuring exercises.

While the short to medium term prospects of the region do not appear to be too encouraging, many of the countries have enormous natural and agricultural resources which, if they are exploited efficiently, should provide the means to

This paper arises from the authors' participation in UNIDO missions to the Central Asian Republics of Azerbaijan, Kazakstan, the Kyrgyz Republic and Uzbekistan in 1994 and 1995. It was prepared while the first author was a visiting scholar at the Centre of Planning and Economic Research (KEPE), Athens. The support of the Centre and its staff is gratefully acknowledged. However, the opinions expressed in the paper are solely the responsibility of the authors. 
finance wider and sustainable economic development. For example, Kazakstan has already proven oil reserves equivalent to 17 per cent of those of Saudi Arabia and a large portion of the country's better oil prospects have yet to be evaluated. In the mean time, one of the major challenges facing the region's governments is reforming the existing industrial sector so that it is adjusted to the new economic situation and attains a dynamic flexibility so that it is able to compete effectively with the volume of imports that may be expected to begin to expand rapidly once the foreign exchange constraint is loosened.

This paper considers the impact of the transition process on the operations of seven large state-owned enterprises drawn from four industrial subsectors, namely, mining and ore processing, metal refining, textiles and garments, and military conversion. ${ }^{1}$ The case studies are necessarily brief and are presented to illustrate a small portion of the problems facing enterprise management and government agencies responsible for the industrial sector in the four republics. Inevitably, they cannot do full justice to the enormous complexities of the situation. In the last section, implications will be drawn for industrial restructuring exercises and the new role for the state in the increasingly marketoriented economies of the region. An Appendix provides descriptive statistics on the performance of the economies of the four Republics.

\section{Implications of the transition process for restructuring large state enterprises in central asia}

Prior to the break up of the Soviet Union in 1991, governments of the region had little or no influence over economic or industrial policy. Generally, allUnion, vertically-organised industrial ministries based on Moscow controlled the development of particular sectors in accordance with the dictates of the central planning mechanism with scant reference to the authorities of each republic. For example, the Kazakstan government claims that before 1991, 90 per cent of its industry was controlled from Moscow via all-Union ministries so that, at independence, there were no national institutions with experience of developing and managing industrial policy or of supervising state-owned enterprises. The same situation prevailed in the other republics of Central Asia. Unsurprisingly, the authorities have found it difficult to develop a strategic vision for the industrial sector. At a more prosaic level, it has proved very difficult to establish effective mechanisms for supervising the vast portfolio of enterprises inherited from the former Soviet Union.

1 The enterprises were visited during July-August 1994 as part of a UNIDO mission to central Asia. Since some of these enterprises are unique to particular countries their exact national location will not be specified in order to protect the anonymity of the management teams of particular enterprises. 
A number of implications can be drawn for enterprise reform from the structural adjustment process that has been underway in Central Asia since 1991. First, the industrial policy environment in each of Azerbaijan, Kazakstan, the Kyrgyz Republic and Uzbekistan has remained unstable and uneven in its impact but is evolving rapidly. The loss of centralised direction from Moscow and the largely unexpected devolution of policy responsibility to the NIS of Central Asia left a policy vacuum and sometimes chaotic conditions. The governments and administrations of the NIS, prior to 1991, had very little experience or expertise in industrial policy development, planning or implementation. Perhaps more critically, there was no established expertise in supervising the very considerable portfolio of state-owned enterprises inherited from the former Soviet Union. Moreover, policy makers were not supported by a rigorous and professional statistical service used to conducting censuses of production and employment. Indeed, statistical data collected during the Soviet Union's existence was bedevilled with misinformation. There are today, therefore, few reliable benchmarks against which to measure the progress of reform.

Second, the economic structure of the economies of Central Asia were severely distorted by the operation of the central planning mechanism with its biases in favour of heavy industry and industrial location decisions determined according to the political priorities of the all-Union government. The independent but parallel power structures of the military-industrial complex added an additional distorting factor to the industrial heritage of the region. For a long period, the countries of Second, the economic structure of the economies of Central Asia were severely distorted by the operation of the central Central Asia were closed to outside influence during which time the administration in Moscow systematically fostered inter-republican manufacturing networks in order to encourage mutual trade, transport and communications dependence, and political integration. Technological development and technology transfer were also Moscow-driven, according to the 'logic' of central planning and administered prices. With the dissolution of the USSR and the final collapse of the rouble zone in November 1993, the fundamental political logic and basic mechanisms of inter-Union trade disappeared.

Third, in the absence of convertible currencies, there was a sudden lurch towards balanced trade primarily based on barter transactions. Demonetised transactions have a number of advantages in the highly inflationary and chaotic regulatory environment that still prevails in the region. Both parties are usually able to avoid, or at least substantially reduce exposure Third, in the absence of convertible currencies, there was a sudden lurch towards balanced trade primarily based on barter to payment default, foreign exchange risk and government retention requirements, export taxes and, where the transaction is 
off the balance sheet, credit controls and producer taxes. ${ }^{2}$ Of course, a whole new set of risks (and opportunities for arbitrage) are also created by the reliance on trading physical product.

Four, the transportation system of the region which is still centred on Russia, has become an important element of regional geopolitics and source of political risk for investors, domestic and foreign alike. Turkey and Iran are also significant players in the regional transportation system and are eager to increase their influence (and revenues). Because it takes a considerable amount of time and money to construct new transport links over the considerable distances and harsh terrain of the region, transport politics can be expected to play a critical role in the economic development of the region for the foreseeable future.

Five, rapid price inflation, rising interest rates and domestic currency depreciation, widespread demonetisation of trade and loss of fiscal subsidy from Moscow have all weakened the credibility and stability of the political regimes of the region. However, unlike in central Europe, the reforming regimes are all direct successors of the communist party. As a consequence, political disputes tend to be between leaders of political factions over the distribution of power and the state's largesse, rather than over differences in policy. ${ }^{3}$ This variety of clientelist, personality-based politics tends to foster an opaque policy environment and corruption, despite the best efforts of reformers to write progressive commercial law and administrative codes. The chronic shortages of professionally competent and experienced officials to conceptualise, write and implement the various policy instruments, laws and codes that have been introduced since 1991 also impedes progress; and the continuing budget crisis of all governments in the region makes it difficult to pay professionals appropriately, even if they were available.

In the next section are presented brief case studies of the operational challenges facing typical examples of large state-owned enterprises in the four Republics. They are intended to illustrate the difficulties facing any attempt to undertake enterprise restructuring to facilitate progress towards commercialisation and marketisation in the region.

2 The tradition of barter trading goes back to the 'shortage economy' and the central planning system where scarcities of physical product was often the hard budget constraint.

3 Of course, after the second free general election after 1989, liberalising regimes in central and eastern Europe were all replaced with post-socialist regimes, with the sole exception of the Czech Republic. Even so, political debate remains vigorous in most central and east European countries. In the Central Asian republics, post-socialist regimes have been autocratic and prone to suspending parliament, ruling by decree and, sometimes, abusing human rights. In general, opposition parties are tightly controlled. 


\section{Examples of state enterprises in the four republics}

\section{Mining and ore processing}

The mining and ore processing enterprise described here is located in a remote self-contained community in one of the republics. The mine was originally opened using prison labour in 1953 (the prison is now closed). The facilities consisted of a pit mine 200 meters deep which was about 80 per cent exhausted, ore grinding mills and a froth flotation plant for producing heavy metal ore concentrates of copper, lead, zinc and barium. The barium ore was supplied from another mine. In 1991, the complex employed 2600 people; by 1994, the number had dropped to 1700 . Most of those leaving were skilled and not nationals of the country. In the summer of 1994, the enterprise was confronting a rapidly deteriorating situation and was on the verge of collapse to the extent that management had been unable to pay the work force for two months.

The enterprise faced numerous technical problems in the plant: the equipment was obsolete; and if still operational, the equipment lacked proper maintenance and spare parts. The plant had also generated enormous environmental damage in the locality through pollution of air, water and soil. For example, ore tailings that have been accumulated over decades of aggressive exploitation of the mine are stored in an open lagoon with a surface area of 38 hectares with little attention paid to long term consequences.

While old economic ties and structures had broken down, the mining company was economically too weak to negotiate viable new ones. In the transition to a market-oriented economy, the company had been left to fend for itself, theoretically an operating subsidiary of a state holding company, but in reality surrounded by rigid financial constraints and a paralysing lack of working capital. With no money with which to pay for necessary inputs, including energy, it was subject to major periodic work stoppages. Its customers were little better off and so frequently did not pay for ore concentrates on time. The potential human tragedy waiting at the end of this particular inter-firm debt chain was the welfare of the mining town which was almost entirely dependent on the mining complex for its survival, not least when winter temperatures fall to $-40^{\circ}$ Celsius.

\section{Metallurgical Industries}

Two examples are provided to highlight the challenges facing capital intensive enterprises producing basic commodities, namely aluminium and steel as they reorient their activities to reflect the new economic conditions in the region. Both plants are major regional producers, established to exploit local ore deposits and energy sources, and have operated Russian metal refining and smelting technology for forty years. While there have been some incremental improvements in process technology in the past, the core process has remain the 
same. With the opening up of the region to Western engineering consultants, strategic metallurgical industries have received many proposals for modernising plant. The difficulty for government officials and enterprise management is that the proposals rarely involve injections of new foreign capital. Rather the foreign partner expects to receive the capital invested back in full within five years.

\section{Aluminium smelting}

The smelter was completed in the 1950s to a 1940s Russian design to exploit local alunite deposits and the then surplus electricity. The alunite, (now supplemented with imported African bauxite in the ratio of $30: 70$, alunite : bauxite) is processed into alumina in a plant $300 \mathrm{~km}$ away from the smelter. The rated capacity of the smelter was 55,000 tonnes per year but by 1994 output was around 10,000 tonnes, from about a quarter of the cells which still remained operational. Air and ground water pollution from fluorides and alumina dust was severe: exhaust air scrubbers from the smelter had been disconnected some years ago due to a design fault and not replaced. Had the smelter been operating at full capacity it would have taken $120 \mathrm{MW}$ from the electricity supply but was actually using around 50MW which was fortunate since the plant was subject to load shedding in winter due to power shortages. In addition to the aluminium smelter, the enterprise owned a brass smelter of 10,000 tonnes per year capacity but this was shutdown since production was based on processing non-ferrous scrap form the former Soviet Union which was no longer available at an economic price. There were also two continuous casting lines for zinc and aluminium bar which were operated occasionally when a firm order was in hand. By 1994, it was clear to management that the aluminium smelter, the core business of the enterprise, was gradually losing productive capacity due to lack of investment and spare parts and was close to the point at which it would be no longer economic to operate. The enterprise employed 2,600 people.

The proposal from Western consulting engineers was to completely replace the existing Russian technology with modern process technology that was technically, environmentally and commercially sound. A number of problems faced the government and the enterprise management in evaluating the proposals. Standard investment appraisal techniques were of only limited use in the operational environment of the country concerned because of the political risks attached to a large, capital-intensive, export-oriented investment. While commercial risk could be reduced to an acceptable level for foreign financial institutions by denominating loan payments in aluminium ingots tradable on the London Metal Exchange, political risk could only be covered by government guarantees, which in turn had long run implications for future industrial policy. If the government chose to do nothing, the smelter would close.

External political risk in the Caucasus region (discussed above), was particularly difficult to estimate. Domestic political risk (sensitivity of the 
investment to changes in policy environment) was also hazardous to estimate in a situation where economic reform was both incomplete and evolving in response to unpredictable pressures, both exogenous and endogenous. For example, any new smelter would only be economically viable operating at a higher capacity than the existing plant, (though more efficient in terms of energy used per kilo of aluminium produced). Any new plant, therefore, required more electricity and larger quantities of alumina. The state electricity utility needed to build a new power station and transmission lines because existing plant was already of insufficient installed capacity and was long over due for replacement. In the interim period, significant upgrading of existing transmission lines is required.

Western aluminium smelting technology has developed on the basis of sandy alumina extracted from bauxite, while Russian designed smelters use floury alumina extracted from local alunite. Unsurprisingly, Western consultants were proposing that the new smelter should switch entirely to imported bauxite and recommended that the locally produced floury alumina be exported to Russian aluminium smelters.

The viability of the investment depends critically on four factors: first, the government's medium to long term energy pricing policy; second, world aluminium prices; third, whether the security and cost of rail transport for imported bauxite, exported aluminium ingots and floury alumina can be negotiated with the Russian authorities at an acceptable price; and third, the likely demand and price for floury alumina exports to Russian smelters. A fifth factor, the introduction of modern management systems and procedures, and training the management team to use the new methods and run the new smelter efficiently is also vital, if the easiest to control.

\section{Steel production}

The second case concerns an integrated steel plant located in another republic. The enterprise and its associated companies employed around 30,000 people. The adjoining town with a population of a quarter of a million people was almost totally dependent on the steel works for its economic well-being. The town was also the major direct recipient of substantial air and water borne pollution from the plant. In addition to steel making, the company had accumulated fairly substantial sideline businesses: a plant for making synthetic detergents for domestic uses, a garment and sock knitting factory and seven state farms producing, among other things, 17,000 tonnes of potatoes in 1993 and considerable amounts of beef, wheat and vegetables.

The present plant produced over 4 million tonnes of carbon steel products per year. About three-quarters of its output was exported, mostly to Russia and the 
NIS. With the recent opening of rail links to western China, the company was developing a promising Chinese market. ${ }^{4}$ The enterprise had been subject to considerable disruption as a result of the break up of the Soviet Union; it was previously an integral part of the all-Union steel industry. The large volumes of cross-border transactions, the rapid and unpredictable changes in prices and the extreme slowness of the banking system had encouraged the widespread use of barter trade, even in domestic transactions with the mining industry. It was claimed that the slow operation of the banking system and the government's foreign exchange retention requirements amounted to a 33 per cent tax on export earnings in 1994.

The government was evaluating a request from the management of the steel combine for a government guarantee for a loan of nearly $\$ 700$ million from a Western banking consortium to finance the installation of a continuous casting plant and modernisation of the coking plant (a major source of atmospheric pollution). The main argument in favour of the continuous casting plant revolved around the superiority of the technology compared with the older three-step process using converters, slabbing and blooming mills. Apparently virtually every steel plant in the former Soviet Union was contemplating changing to continuous casting technology and the combine's management were worried about losing competitive advantage.

Perhaps the most striking aspect of the operation of the steel combine was the scale and complexity of the different challenges facing the undertaking and the difficulties, both political and economic, the government faced in deciding whether to back a project equivalent to more than 40 per cent of the government's entire annual revenues. It was noticeable that within the management team the case for the new investment was presented almost exclusively in technological terms. There was no evidence of an attempt to justify the project in terms of a corporate strategic plan, marketing plan or cash flow forecast for the enterprise as a whole. The profitability of the entire enterprise, should the new investment go ahead, would become significantly more dependent on operating at near full capacity, yet the resort to barter trading for essential inputs added considerable downside risk in terms of security of supplies to support continuous steel casting. It may have been no accident that the Soviet Union's planners did not favour continuous casting technology.

Clearly, in the context of a market-oriented economy, any enterprise contemplating a large strategic investment would normally appraise the project within the parameters of an overall strategic development plan for the

4 Some estimates suggest a short fall in steel making capacity of 70 million tonnes in China by the year 2000 . 
enterprise. Yet enterprise management in Central Asia have no experience or training in the preparation of market-oriented strategic plans for individual enterprises. Implementation is even more problematic as enterprises typically lack an active marketing function and sales team to find and secure markets, or a financial management function and supporting management accounting and information systems to enable the necessary control of cash flow. The steel combine was no exception. Senior managers were certainly aware of the technological backwardness of the enterprise they managed, but were also justifiably proud of their ability to maintain production from obsolete equipment that should have been written off many years ago. However they almost certainly under-estimated the logistical, marketing and cash flow implications of the high performance required of the proposed modern capital intensive process technology.

The immediate problem for the government was how to respond this kind of proposal. As in the case of the aluminium smelter, the downside of doing nothing was eventual closure of a strategic industry and significant loss of jobs, mostly held by ethnic Russians in a politically sensitive region near the Russian border. Privatisation offered no immediate solution because the real constraints on enterprise performance were as much to do with the enterprise's organisational structure and strategy, and the managerial capacity and capabilities of its senior management as with property rights and incentives. What was required was the preparation of a corporate restructuring and development plan that encompassed all of the revenue generating and consuming activities of the enterprise.

From that planning exercise, management needed to develop a restructuring programme that focused in the short-term on improving the enterprise's cash flow position. This required attention to defining core and non-core activities, introducing active financial management and supporting management accounting systems and a plan for disposal of surplus assets. A marketing plan and an appropriate marketing department and sales team also needed to be established. Only after reviewing the enterprise's cash flow position and its markets was it appropriate to review the production plant and its future development to meet market needs, existing and projected, and to improve pollution control. ${ }^{5}$

5 Of course, the analysis of the combine's cash flow position would have indicated a number of distortion caused by government intervention in its economic and financial relations and these may need short-term compensation, for example, any foreign exchange retention requirement or tax on exports. 


\section{Textile and garment production}

The country that is the location of the textile and garment manufacturing enterprises described in the next two case studies, ranks in the top ten producers in the world with an annual output of more than 4 million tonnes a year. Unusually, by comparison to other major cotton producers in the developing world, processing capacity in the country was limited to less than 20 percent of raw cotton output reflecting the Soviet planners' strategy of developing the country as a source of cheap cotton. ${ }^{6}$ Various foreign companies have already established modest non-equity alliances with local producers to manufacture under contract, partly because export of raw cotton was subject to close government control. ${ }^{7}$ Deals usually involved some form of trade-financed purchase of machinery and spare parts purchases together with technical assistance with production and design.

\section{Textile production}

The major cotton yarn, textiles and industrial sewing thread producer in the country employed around 13,000 people on three sites. The major site employed 9,000 people. Output in 1993 was 14,600 tonnes of yarn, 2.6 million standard bobbins of sewing thread and about 100 million metres of grey cloth. The input price of raw cotton was set by the government after negotiations with producer co-operatives. Domestic prices for finished production were also effectively controlled by government through the requirement that the enterprise sell 85 per cent of its output to the state-owned light industry holding company. Although officially independent, the holding company had to negotiate transfer prices within the domestic market with the government and agree on which organisations in the domestic market were to be permitted to buy the output for further processing. The majority of the remaining 15 per cent of production was used for barter with Russia and other NIS republics for spare parts, chemicals and dyes. The domestic transfer price was significantly lower in terms of revenues received by the producer than the export price.

The breakdown of supply chains from the former Soviet Union was seriously hampering the performance of the finishing section of the textile enterprise by causing shortages of chemicals and dyestuffs. Barter trading was being used to relieve the situation. While input and output prices were substantially controlled by the government along with capital purchases, there was no possibility or incentive for the management to accumulate reserves except through their ability to barter the officially permitted 'marginal' 15 per cent of output to

6 Pakistan, for example, has succeeded in increasing its domestic processing capacity to nearly 100 per cent of its cotton crop from around 20 per cent twenty years ago.

7 The President himself must approve foreign sales of more than 5,000 tonnes. 
finance immediate purchases. Some of the government allocation of bales of raw cotton could also be unofficially diverted for barter purposes, although government control of cotton exports was apparently strict. Barter trade in the textile industry was relatively easy to organise since raw cotton, industrial thread and grey cloth were tradable commodities with recognised market prices.

The enterprise's management used any remaining surpluses from barter trade for purchase of spare parts and a limited number of new machines. More substantial modernisation of the plant remained dependent on direct budgetary support from the government. This had not been forthcoming since the collapse of the Soviet planning mechanism. For example, advantage could not be taken of the recent upgrading of the fabric finishing and printing section, the last project in the plant to benefit from Soviet capital investment. Thus while the finishing section had the capacity to process fabric up to the international standard of $164 \mathrm{~cm}$, the plant's weaving section could only manufacture to the old Soviet standard of $85 \mathrm{~cm}$. Senior management of the textile plant were able to cite a number of similar examples of where the slow incremental process of equipment purchases during the Soviet era had resulted in losses of efficiency due to incompatibility and mismatches between different vintages of machinery in various sections of the plant. In some sections it was also proving necessary to cannibalise some of the older machines as sources of spare parts.

Paradoxically, then, in this republic, many of the classic features of production in a 'shortage economy' were exemplified by the operation of the textile plant. The ultimate hard budget constraint was physical unavailability of product; where new equipment was introduced, it was invariably used inefficiently because it was rarely compatible with the existing stock of machines, a result of the exigencies of the old capital allocation system; and continued state control of input and output prices prevented any financial autonomy of the enterprise except where barter trade was possible. Under the conditions in which the factory operated, the management team was forced to concentrate on production issues . It was simply the critical activity for the survival of the plant. In any case, management was powerless to 'manage' other functions such as finance or marketing as these were administered externally by other state agencies.

\section{Garment manufacture}

The enterprise described here, located in the same republic as the textile enterprise, was founded in 1942. In 1994, it manufactured a variety of cotton knitwear and hosiery for the domestic market. Current output was 20 million pieces manufactured in 300 different designs. The enterprise employed 3,500 people. It was facing a number of production constraints particularly with respect to the quality of yarn supplies and dyestuffs. These constraints prevented management from improving the quality and diversity of production. Even though the enterprise had recently installed a modern dye house using 
Western European technology purchased before the dissolution of the Soviet Union, poor quality of locally available yarns and dyes and antiquated knitting machines precluded manufacturing to international quality standards. Since the break up of the Soviet Union, the company has also been unable to buy synthetic fibres for blending with cotton. Nevertheless, despite the poor quality of the company's products, there was no serious domestic competition; foreign imports were sporadic and higher priced due to foreign exchange shortages; and tight restrictions on private importers and retail outlets prevented significant imports of second-hand clothes.

The management of the garment enterprise claimed to be eager to produce internationally competitive products and certainly reported that they did not consider selling their garments in Russia as 'real' exporting. However, the company relied on the state holding company for light industry to organise sales and there was no company-based marketing function to develop marketing strategies or carry out market research. In short there was no provision for customer feedback to the garment design process. Samples of attempts to copy a West European branded product demonstrated that the major constraints on developing export products was the quality of local cotton yarn and dyestuffs. While the finish of garments on display in the company's exhibition room was comparable to Western samples, the knitted fabric had several faults derived from poor quality yarn and colours which appeared 'faded'.

Enterprise management identified the major bottlenecks facing the development of the enterprise as being primarily technical in nature. Given the company's monopoly position, there was virtually no incentive to innovate with product design. Again as in the textile plant described above, the technical constraints imposed by obsolete technology and poor quality raw materials such as yarn and dyestuffs meant that management's major function was to prevent breakdowns and to keep production going more or less independently of market needs. The absence of a modern management and cost accounting system restricted effective action to drive down unit costs.

\section{Military conversion}

Two examples from another republic, a military electronics enterprise and a torpedo manufacturing and assembly enterprise, serve to illustrate the enormous problems confronting attempts to convert enterprise units of the former Soviet military-industrial complex located in the Central Asia to civilian production.

After the collapse of the USSR, the Soviet military procurement system contracted sharply to serve Russia's very much reduced requirements only from Russian territory. All component supplies and purchase orders to the Central Asian republics ceased and production collapsed. With no work, most of the labour force was laid off, initially on full pay but as the credit squeeze has begun to bite most now receive no pay. Vast complexes of buildings were all 
that remained of the former production regime ${ }^{8}$, sometimes full of derelict work stations, sometimes containing under used, state-of the-art machine tools, and mostly devoid of employees.

Attempts to convert the military electronics assembly enterprise to civilian production was stalled by, among others, lack of commercial expertise of the existing management, the small size and remoteness of the domestic market, poor commercial and logistics infrastructure, ${ }^{9}$ and shortages of foreign exchange with which to purchase components. Fundamentally, all the enterprise had to offer investors, local or foreign, were buildings, hardly an obvious source of comparative advantage in a remote location beset with infrastructural inadequacies. The enterprise required liquidation and the premises leased or sold to employees and others wishing to establish private small enterprises able to 'make do' in the barter dominated domestic market of the republic.

The second example of the challenges facing military conversion exercises was a torpedo manufacture and assembly facility. The plant had originally been relocated to Central Asia during World War II. It had since undergone periodic upgrading and expansion as the Soviet submarine fleet had grown. It was one of four such enterprises, the only one outside Russia. The main production activities were split between manufacture of standard electrical components, assembly of the electronic guidance systems for the torpedoes (from components supplied from Russia and the Ukraine), machining of torpedo casings and final assembly. The finished torpedoes then used to be air freighted to Soviet submarine bases several thousand kilometres away. With the end of the Cold War and Russian military retrenchment, production of torpedoes was stopped outside of Russia. The producers in the Central Asian republic were also prevented from supplying the export market by dependence on Russian components.

The only substantial civilian product that the plant manufactured was various types of high speed centrifuges. These required the use of the precision machining facilities of the enterprise and incorporated locally produced electric motors and control systems, though components still had to be imported. Management estimated that only 8 per cent of the plant's capacity was in use, although around 1500 employees were still nominally on the payroll. As in the case of the military electronics enterprise, a paralysing mix of technical, financial and commercial factors constituted major barriers to effective conversion to civilian production. Specifically, the domestic economy had only limited requirements for precision engineering products, the export potential of

8 An average sized military equipment plant usually covers 25-35 hectares.

9 For example, in 1994, there were no scheduled airline connections outside the country and petrol had to be bought from private tankers that sold from the roadside. 
large machined components was limited by high transportation costs, there was no supporting indigenous steel or non-ferrous metal industry and external supply chains were plagued with problems (discussed above).

While the technical and skills base of the work force was not in doubt, the management team had no experience of seeking out and developing a customer base in the domestic market, leave alone international markets. The enterprise already had problems sourcing its components for medical centrifuges and was forced to rely to a large extent on barter arrangements with its major Chinese customers. Given the magnitude of the problems afflicting the enterprise's supply chain, it seemed rather unlikely that the enterprise would be able to attract foreign subcontracts to take advantage of its sophisticated computercontrolled, flexible machining systems. Unfortunately, production facilities, however sophisticated, are of no use without secure supplies of materials for processing and appropriate customers.

\section{The challenges for industrial restructuring in the central asian republics}

With the slow pace of privatisation in the Republics and the absence of a welldeveloped private sector, many of the large state-owned enterprises of the type described above will remain in the public sector for some time to come (Henley/ Assaf, 1995). ${ }^{10}$ It is therefore vital in this interim period that governments continue to press ahead with improving efficiency, productivity and the competitiveness of existing state enterprises. In this context, industrial restructuring has become the major challenge for the industrial sector. However as the case studies presented above demonstrate, existing enterprises in the region face acute problems and are increasingly turning to already stretched governments for help with funding working capital and purchasing new capital equipment. At the same time, the international financial institutions (World Bank, IMF and EBRD) are insisting on strict credit control to the state-owned sector and significantly positive interest rates on all loans as a condition of their financial and technical assistance to governments.

Yet political stability in the region is too fragile to absorb high levels of unemployment. The frequently acknowledged and discussed need for social safety nets has rarely been followed by adequate funding to support benefits

10 The garment and textile companies in the republic described above were nominally privatised in that 'ownership' had passed to the employee collective but the government is in the process of reversing this policy. It has been found tin practice hat merely transferring ownership to the existing employees does not change the status quo and indeed makes the adoption of effective corporate governance and management-driven strategies very difficult. 
programmes for those disadvantaged by the transition process. Heightened social pressure will surely follow major closures. Naturally, restructuring needs to avoid re-establishing the previous conditions for inefficient production but instead should create a sound basis for developing competitiveness, growth of output and securing employment.

Deteriorating performance and eventual bankruptcy of some industrial enterprises are inherent features of a dynamic industrial development process. However, this also can indicate inadequate economic and industrial policies and other shortcomings in the business and commercial environment or the result of abrupt changes in key parameters - such as sudden dislocation of supply chains and output markets and sharp increases in the price of vital but previously subsidised inputs such as energy or freight charges. Policy co-ordination is inevitably likely to be problematic when so many elements of policy are novel or being refocused, more or less simultaneously.

Another factor contributing to policy inadequacies is the relative inexperience of the officials and advisers preparing and implementing the policies and the under-developed consultation procedures of the Central Asian Republics. The formulation of the extensive range of unfamiliar and untested industrial policy measures required to support structural adjustment programmes at the sectoral and sub-sectoral levels would be a daunting task even for an experienced and well-paid civil service. However, in the region, civil servants are generally badly paid and poorly trained to oversee the reform of the industrial sector. Inevitably, the largely unreformed government bureaucracies rely on the advice of directors of state-owned enterprises. Thus, for example, in Azerbaijan, the director general of a state holding company holds the rank of a minister and answers to the prime minister's office. It would be surprising if such powerful chief executives passively accept reforms threatening their entrenched positions.

Normally, ministries prepare legislation which is submitted to parliament with little public debate or examination. Sometimes shortcuts are taken such as copying legislation from the Russian Federation without any attempt to adapt it to local conditions. While independent chambers of commerce and employers' associations are beginning to exert some influence on the drafting process, subsequent amendment of legislation typically depends on the uncertain process of lobbying the president's office before legislation receives presidential assent. Creating the policy environment to support enterprise reform and mechanisms to efficiently implement restructuring at enterprise level remains one of the major challenges for governments in Central Asia. The task is enormous for in all four Republics most enterprises are in need of restructuring.

The regional dimension of enterprise restructuring also needs to be addressed As indicated in the case studies above, several communities within individual Republics were developed as 'one-enterprise' towns. The threat of closure or major retrenchment of an enterprise that is the basis of the livelihood of a 
community spells economic and social disaster for those dependent on the enterprise. The situation is particularly acute in Kazakstan because of its vast size and the geographical isolation of its mining complexes. The extensive social and welfare responsibilities of large state-owned enterprises further exacerbate the consequences of closure for the community involved. It is therefore vital to develop restructuring plans that take account of local interests and have built into them scope for effective local discussion of the implications of restructuring and resources to help local communities develop ways of ameliorating the situation.

The results so far achieved with enterprise restructuring in the Central Asian Republics has been extremely limited. While macroeconomic reform is now well-entrenched, the supply side response at enterprise level to changes in macroeconomic parameters, so far has been much less than in Central and Eastern Europe, sometimes even undetectable. It is now rather clear from Central European experience that spontaneous restructuring of large stateowned enterprises led by the existing management team is exceptional. More usually restructuring is induced by selective intervention by state agencies or new shareholders following privatisation (Amsden/ Kochanowicz/ Taylor 1994). This is unsurprising given the complexities of the problems involved. As Rybezynski (1991) notes, restructuring in former socialist states entails major 'operations' on all parts of the critically 'ill' enterprise, in comparison to the more selective approach normally used in turning round the 'sick' parts of Western enterprises. In the case of many of the enterprises in Central Asia, they are not self-contained production units but disconnected segments of a once integrated all-Union production network. The weak legal, regulatory and financial services infrastructure typically found in the region also means there are few professional services to draw on for appropriate advice, guidance and follow up support. Redressing these weaknesses is a major task for nascent governments and their international technical and investment co-operation partners.

\section{The role of foreign investment}

Many of the countries of Central and Eastern Europe have been eager to attract foreign investors to assist with the transformation of previously state-owned enterprises through participation in privatisation either on an equity joint venture basis or through outright acquisition. The countries of Central Asia discussed in this paper have all begun to develop policies relating to foreign direct investment but so far have met with very limited success in attracting foreign investment interest.

The barriers to entry faced by foreign investors in Central Asia are very similar to those aspects of the operating environment causing the crisis in domestic state-owned enterprises: the lack of a clearly defined, stable and transparent 
policy environment; high rates of inflation and a rapidly depreciating local currency; rapidly shrinking domestic demand; inadequate infrastructure and business support services, particularly transport and telecommunications; underdeveloped banking and financial services sector and chronic foreign exchanges shortages. Official policy towards inward investors in all four countries could benefit from further liberalisation, especially through streamlining the approval mechanism and measures to guarantee equal treatment before the law for foreign and domestic companies. ${ }^{11}$ "One-stopshops" to handle inward investment enquiries and proposals are ubiquitous in market economies. A single institution is required in each republic to actively promote investment, to liaise with potential investors, and to act as an intermediary between private foreign investors and government.

Only those investors that can secure their foreign exchange requirements for essential inputs and for repatriating profits through trade have so far shown real interest in the region. Three kinds of investors have begun establishing themselves. Firstly, those in extractive industries (oil, gas, minerals) pursue a strategy of securing their payments by export of product but face severe and continuing logistic problems in maintaining operations. There have also been examples of irregular tendering procedures in assigning concessions to international companies. For example, the Kazakstan authorities awarded the Vasilkovskoye gold mining concession to a local company which then brought in a major Canadian gold mining company cutting out the Australian mining company that had spent several million dollars exploring and proving the reserves (Financial Times, 9 August 1995).

The second type of foreign investor bases production on the assembly of prepaid kits, for example vehicle assemblers in Kazakstan and Uzbekistan. Although the domestic markets are not large, for a modest investment of less than US\$ 10 million it is possible to purchase premises and start assembly operations. High effective rates of protection from competitors' products are available and the regional market is still virtually undeveloped. The logistics of importing kits is difficult and costly but has the advantage of minimising reliance on domestic inputs in the short run while experience of working in an unknown market is built up.

A third type of foreign investment that has so far involved a rather limited amount of equity is investment in plant processing and manufacturing products with a high local resource content. The major exception is the investment by Reynolds Tobacco (US) and Philip Morris (US) in Kazakstan and BAT (UK) in Uzbekistan to manufacture cigarettes using locally grown tobacco. Promising

11 It is widely believed by foreigners that tax collection is highly inefficient and many local companies pay very little tax. For example, in the Kyrgyz Republic, VAT revenues only increased by 30 per cent in 1993 while prices increased by 300 per cent. 
areas for foreign investment in the medium-term are likely to be in the processing of cotton, wool, skins and hides. Already some buyers from OECD countries have been signing subcontracting agreements with cotton textile plants in Kazakstan and Uzbekistan. Turkish companies have been active in establishing production sharing agreements with skins and hides producers in Kazakstan and Azerbaijan. In Uzbekistan, production agreements have been established in the textile sector with several different countries including France, Italy, Austria, Germany and South Korea. The depth of these ventures is so far relatively shallow, involving very little equity participation. The foreign partner typically supplies machinery, specialist raw materials, accessories and technical support in exchange for finished products delivered against a contract.

Despite the abundance of oil and natural gas in the region, the world's chemical industry has shown little interest in becoming involved in downstream processing of petrochemicals. It appears to be waiting to see firm evidence of returns from the development of oil and gas concessions in Azerbaijan, Kazakstan and Uzbekistan before committing itself to downstream investment. This evidence could well be forthcoming in the near future.

\section{The role of technical assistance}

The scale and scope of enterprise restructuring and reform required in Central Asia is simply beyond the present capacity and capabilities of the governments of the region. As indicated above, state budgets are already over stretched and inexperienced civil servants are struggling to maintain the delivery of existing services. The collapse of state enterprises and/or the transfer of social welfare obligations from enterprises to the state are creating additional demands on the government budget.

While significant progress has been achieved in all four republics with reforming macroeconomic policy and establishing a framework for the development of a market-oriented economy, very little has been achieved at the enterprise level. So far, technical assistance provided by the international financial institutions and bilateral donors to state-owned enterprises has hardly scratched the surface of the problems involved in restructuring enterprises.

Reform of the state sector is inextricably linked to private sector development. Unfortunately, private firms usually have to fight for survival against an extremely complex state bureaucracy that remains notably resistant to relaxing controls on private sector activity. However, without a vibrant private sector there is no alternative employment for workers displaced by restructuring exercises, no supply of support services essential for the efficient functioning of a market economy and no competitive pressure to challenge the monopolistic practices of the state sector. 
Unsurprisingly, privatisation of industry has achieved very little to date beyond formal transfer of ownership, usually to existing management teams and employee collectives (Varanese 1995). In the absence of entrepreneurial talent, venture capital and an active financial services sector, there are few incentives for senior management to undertake the onerous task of enterprise restructuring: it easier to accumulate debt and hope for financial assistance from the state. Without substantial external support for enterprise restructuring, there appears to be little prospect of existing management teams being able to help themselves.

Assistance is required at many levels. First, governments require advice and assistance at national level with identifying the prospects of the existing stock of state enterprises, then devising a realistic strategic "vision" of investment requirements and the social implications of anticipated closures resulting from industrial restructuring. Line ministries responsible for restructuring also need reform so that they are able to develop market-oriented industrial policy and industrial development programmes. Staff require training in project appraisal, and monitoring and evaluation techniques, and commercial risk assessment so that they are competent to negotiate with the management of state enterprises, supervise privatisation activities and assess potential foreign investors.

Second, at a sub-sectoral level, government agencies need to be developed with the capacity to assess the competitiveness and commercial viability of state enterprises and prospects for rehabilitation. Diagnostic services required may include assessment of the management and organisational structure, the marketing and sales function, cost accounting and financial control systems, technical and technological support of product design and production processes and the preparation of strategic business plans. Programmes will then be required to meet specific training needs identified to support restructuring and privatisation.

While international consulting companies are active in the region funded by a variety of technical assistance programmes, domestic business services companies are undeveloped. There is clearly scope for public - private partnerships to foster the formation of domestic consultancy and business services companies. Technical assistance might be directed towards training local consultants in how to go about advising enterprises to adopt modern business planning techniques, management accounting and cost control systems, marketing and market research, product design and development and how to cope with the rapidly changing legal and regulatory environment. Countries further advanced in the transition process in Central and Eastern Europe could be a valuable source of expertise and associated knowledge of the Russian language and familiarity with the institutional structures left behind from the former Soviet Union. International consulting companies operating in the region would clearly benefit from an increased pool of local expertise and should be 
encouraged to form alliances and joint ventures with emerging domestic consulting companies. At the same time, governments have to establish transparent tendering procedures for consultancy contracts in order to avoid moral hazard in an immature and thin market.

A third area for technical assistance and for public - private partnerships is in developing the banking and financial services sector. A competitive and proactive banking and financial services industry is an essential catalyst for enterprise reform and restructuring. While the sector has begun to attract substantial technical assistance from the IMF, World Bank and EBRD, there are very real limits as to what can be achieved without competition and foreign commercial banking expertise. Another major constraint is the shortage of bankers with knowledge of commercial risk appraisal and financial intermediation. Major support from the international community - particularly from the EBRD - may be required in this area. An important focus of technical assistance and financial support from the international financial institutions has been bad debt sanitisation and the design of debt workout regimes. Progress has been slow and soft budgetary constraints and subsidised credits for state enterprises are proving surprisingly difficult to eliminate from the system of financial management. There is also a shortage of venture capital for funding restructuring and re-investment in privatised or private enterprises. Current lending is short-term and trade related or state-directed to state enterprises and/or based on inter-firm credits. The state-owned commercial banks of the region would undoubtedly benefit from 'twinning' arrangements with Western commercial banks. ${ }^{12}$

A fourth and vital area for technical assistance is encouragement and support of entrepreneurship. Small and medium sized private enterprises (SMEs) were almost totally absent from the industrial structure of the Central Asian economies before the break up of the former Soviet Union. As a consequence, governments in the region have no experience of targeting the specific needs of SMEs and are ill-equipped to develop policy instruments such as small business incubators, advisory centres and credit lines for entrepreneurs. Technical assistance is desperately needed to assist the authorities in creating a policy environment in which SMEs are positively encouraged through the relaxation of administrative and legal restrictions on private enterprise and the provision of efficient support systems. Major constraints on the growth of an independent entrepreneurial class, as already noted above, is the lack of medium term credit

12 The World Bank, for example, has supported successful 'twinning' arrangements with Western banks in Poland whereby modern banking techniques are introduced into the management of state-owned commercial banks through technical assistance from foreign banks. 
and a chronic shortage of local low cost consultancy and other business services to provide the necessary assistance to entrepreneurs.

Undoubtedly, the restructuring and associated down-sizing of large state enterprises will provide many opportunities for the development of new private businesses. However, in the absence of a flourishing entrepreneurial culture, support systems for business start-ups are particularly important, not least as a way of mitigating the effects of unemployment arising from restructuring exercises. Many towns in the region are dependent on a single large employer, especially in Kazakstan where geographical isolation is marked, so that any substantial reduction in employment may spell social disaster for particular communities. Job creation schemes including support for small businesses are thus likely to form an essential component of many restructuring plans.

Finally, there exists an almost unlimited requirement for in-company training and advice in all aspect of modern business methods. The region of Central Asia has been totally cut off from developments in business practice in the market economies of the world. Even in the largest state-owned enterprises, management have no modern management information systems available to them, accounts are still kept according to the standards of the central planning system of the former Soviet Union - that is, they are simply records of expenditure. The ability to develop a marketing plan supported by market research is unknown; product design and development is usually organised as an autonomous activity divorced from any systematic attempt to assess consumer needs; and quality standards are largely dictated by the available supply of raw materials and machinery. Nothing less than a radical change in organisational cultures is required throughout the region, yet organisational inertia appears to be immense.

It is in the area of management training that public - private partnerships are likely to prove most fruitful. While official technical assistance is effective in designing training programmes and mobilising training advisers, and is already doing so on a considerable scale in the region, such training tends to be rather general, is taught off-the-job and is not carried out on a sufficient scale to achieve a critical mass of trained managers in individual enterprises. As a result it is rarely rooted in specific organisational sub-cultures, with the possible exception of training targeted at the banking industry which because of globalisation of the world's financial system has an increasingly universal operating culture. ${ }^{13}$

13 The international oil and mining industries also have many universal features and are well able to fund necessary management training programmes. Extractive industries that attract foreign interest are the exception, the bulk of state-owned enterprises are unlikely to attract significant foreign investment. 
The challenge for the donor community is not only to provide training and management development schemes on a sufficient scale but to create mechanisms that ensure that enterprise cultures support effective management training. One such way is to forge twinning arrangements between Western companies and enterprises in Central Asia so that managers from the region can acquire positive role models from foreign companies they can understand at a technical level. By appealing through the strong scientific and engineering culture of enterprise managers in Central Asia, it should be possible to introduce the 'technology' of modern management practices. This is most likely to be achieved where managers are familiar with each other's operating environments.

\section{References}

Amsden, A.H./ Kochanowicz, J./Taylor, L. (1994): The Market Meets Its Match, Cambridge, Mass.,Harvard University Press.

EBRD (1994 and 1995): The Transition Report, Oxford, Oxford University Press for EBRD.

Economist Intelligence Unit (1995): Central Asian Republics 1994-95, Report 19, London, EIU.

Economist Intelligence Unit (1995): Armenia, Azerbaijan and Georgia, Report 36, Second Quarter, 1995, London, EIU.

Henley, J. S./ Assaf, G. B. (1995): Re-Integrating the Central Asian Republics into the World Economy, in: Intereconomics, Vol. 30, 5 (1995) pp 235-246.

Henley, J. S. (1996): Restructuring enterprises in the economies in transition: Evidence from Poland, in: Cook, P./ Kirkpatrick, C./ Nixson, F.: Transition and Development: Issues in Enterprise Reform and Promotion, London.

IMF (1994): Economic Reviews - Azerbaijan, Washington DC.

IMF (1993): Economic Reviews - Kazakstan, Washington DC.

IMF (1994): Economic Reviews - Kyrgystan, Washington DC.

IMF (1994): Economic Reviews - Uzbekistan, Washington DC.

Naughton, B (1994): Reforming a planned economy: Is China Unique?, in: From Reform to Growth: China and Other Countries in Transition in Asia Central and Eastern Europe, Paris, OECD, pp 73-99.

Rana, P. B. (1995): Reform Strategies in Transitional Economies: Lessons from Asia, in: World Development, Vol. 23/ 7 pp 1157-1169.

Rybezynski, T. (1991): The Sequencing of Reform, in: Oxford Review of Economic Policy, Vol. 7, 4, pp 26-34.

Sachs, J. D./ Woo, W. T. (1994): Understanding the reform experiences of China, Eastern Europe and the former Soviet Union, in: Lee, C. H./Reisen, H. (eds.): From Reform to Growth: China and Other Countries in Transition in Asia Central and Eastern Europe, Paris, OECD, pp 23-48.

UN Economic Commission for Europe (1995a): Economic Survey for Europe, United Nations, Geneva. 
UN Economic Commission for Europe (1995b): Industrial Restructuring in Selected Countries in Transition, United Nations, Geneva.

Varanese, J. R. (1995): Mass Privatisation: A first assessment of the results in the Republic of Kazakstan, in: OECD: Mass Privatisation: An Initial Assessment, Paris, OECD, pp 191-205.

World Bank (1995): Trends in Developing Economies, Washington DC.

World Bank (1993): Azerbaijan - From Crisis to Sustained Growth, Washington DC.

World Bank (1993): Kazakstan, The Transition to a Market Economy, Washington DC.

World Bank (1994): Kazakstan, Economic Report, Washington DC.

World Bank (1993): Kyrgystan - The Transition to a Market Economy, Washington DC.

World Bank (1993): Uzbekistan - An Agenda for Economic Reform, Washington DC.

\section{Appendix}

Table 1: Territory and Population, 1992

\begin{tabular}{|c|c|c|c|c|}
\hline & $\begin{array}{c}\text { Territory } \\
(000 \text { 's km²) }\end{array}$ & $\begin{array}{c}\text { Density of } \\
\text { Population } \\
\left(\text { per } \mathbf{k m}^{2}\right)\end{array}$ & $\begin{array}{c}\text { Total Population } \\
\text { (000's) }\end{array}$ & $\begin{array}{l}\text { Labour Force } \\
\text { (000's) }\end{array}$ \\
\hline Russian Federation & $17,075.4$ & 8.7 & 148,625 & 86,200 \\
\hline Azerbaijan & 86.6 & 83.7 & 7,330 & 4,000 \\
\hline Kazakhstan & $2,717.3$ & 6.2 & 17,057 & 9,300 \\
\hline $\begin{array}{l}\text { The Kyrgyz } \\
\text { Republic }\end{array}$ & 119.9 & 22.4 & 4,518 & 1,730 \\
\hline Uzbekistan & 447.4 & 47.4 & 21,672 & 10,390 \\
\hline
\end{tabular}

Table 2: Relative Weight of Countries in CIS, 1992

\begin{tabular}{|l|c|c|c|c|c|}
\hline & GNP & $\begin{array}{c}\text { Industrial } \\
\text { Production }\end{array}$ & $\begin{array}{c}\text { Consumer Goods } \\
\text { Production }\end{array}$ & $\begin{array}{c}\text { Agricultural } \\
\text { Production }\end{array}$ & $\begin{array}{c}\text { Retail Trade } \\
\text { Turnover }\end{array}$ \\
\hline $\begin{array}{l}\text { Russian } \\
\text { Federation }\end{array}$ & 66.3 & 63.5 & 60.7 & 51.5 & 61.7 \\
\hline Azerbaijan & 1.4 & 1.4 & 1.6 & 1.4 & 0.8 \\
\hline Kazakhstan & 4.8 & 4.7 & 3.8 & 8.0 & 3.7 \\
\hline The Kyrgyz & 0.9 & 0.8 & 1.0 & 1.3 & 0.5 \\
\hline
\end{tabular}




\begin{tabular}{|l|c|c|c|c|c|}
\hline & GNP & $\begin{array}{c}\text { Industrial } \\
\text { Production }\end{array}$ & $\begin{array}{c}\text { Consumer Goods } \\
\text { Production }\end{array}$ & $\begin{array}{c}\text { Agricultural } \\
\text { Production }\end{array}$ & $\begin{array}{c}\text { Retail Trade } \\
\text { Turnover }\end{array}$ \\
\hline Republic & & & & & \\
\hline Uzbekistan & 3.5 & 3.4 & 3.0 & 6.0 & 2.4 \\
\hline
\end{tabular}

Table 3: Intra-CIS Trade, 1994

\begin{tabular}{|l|ccc|cc|cc|}
\hline & \multicolumn{3}{|c|}{ Value } & \multicolumn{2}{c|}{ Average quarterly growth } & \multicolumn{2}{c|}{ Ratio } \\
& Exports & Imports & Balance & Exports & Imports & Deficit $^{a}$ & Surplus $^{b}$ \\
\hline Azerbaijan & 306 & 545 & -239 & -0.4 & -3.7 & 78.1 & - \\
Kazakhstan & 1705 & 3019 & -1314 & 3.6 & 5.8 & 77.1 & - \\
The & 224 & 191 & 33 & 3.8 & -2.4 & - & 17.3 \\
Kyrgyz & & & & & & & \\
Republic & & & & & & & \\
Uzbekistan & 1279 & 1325 & -46 & -28.2 & -4.1 & 3.6 & - \\
\hline
\end{tabular}

(Value in million dollars, growth and ratios in per cent)

${ }^{\text {a }}$ Deficit-to-export ratio; ${ }^{b}$ Surplus-to-import ratio

Source: CIS Statistical Committee

Table 4: Trade with the Outside World, 1993-1994

\begin{tabular}{|l|cccc|cccc|cc|}
\hline & \multicolumn{4}{|c|}{ Exports } & \multicolumn{4}{c|}{ Imports } & \multicolumn{3}{c|}{ Trade } \\
& \multicolumn{3}{|c}{ Value } & Growth rates & \multicolumn{3}{c|}{ Value } & Growth rates & \multicolumn{2}{c|}{ balances } \\
& 1993 & 1994 & 1993 & 1994 & 1993 & 1994 & 1993 & 1994 & 1993 & 1994 \\
\hline Azerbaijan & 351 & 366 & -53.5 & 4.4 & 241 & 296 & -27.5 & 22.9 & 110 & 70 \\
Kazakhstan & 1271 & 1095 & -9.1 & -13.8 & 358 & 514 & -23.6 & 43.6 & 912 & 581 \\
The & 112 & 116 & 46.5 & 3.8 & 112 & 92 & 58.9 & -17.5 & 0 & 24 \\
Kyrgyz & & & & & & & & & &
\end{tabular}




\begin{tabular}{|l|llll|llll|ll|} 
Uzbekistan & 707 & 944 & -18.7 & 33.6 & 947 & 1150 & 1.9 & 21.4 & -241 & -206 \\
\hline
\end{tabular}

(Value and trade balances in million dollars, growth rates in per cent)

Source: National statistics and direct communications from national statistical offices to UN/ECE secretariat; CIS Statistical Committee

Table 5: Real Gross Domestic Product, 1990-1995

\begin{tabular}{|l|c|c|c|c|c|c|}
\hline \multicolumn{1}{|c|}{ Country } & $\mathbf{1 9 9 0}$ & $\mathbf{1 9 9 1}$ & $\mathbf{1 9 9 2}$ & $\mathbf{1 9 9 3}$ & $\mathbf{1 9 9 4}$ & $\begin{array}{c}\mathbf{1 9 9 5} \\
\text { (half) }\end{array}$ \\
\hline Azerbaijan & 94.5 & 93.8 & 72.6 & 55.8 & 43.5 & 36.1 \\
\hline Kazakhstan & 99.0 & 87.4 & 76.0 & 66.2 & 49.6 & 40.4 \\
\hline $\begin{array}{l}\text { The Kyrgyz } \\
\text { Republic }\end{array}$ & 104.8 & 100.4 & 83.9 & 70.6 & 53.0 & 48.3 \\
\hline Uzbekistan & 99.3 & 94.3 & 83.8 & 81.8 & 78.5 & 76.9 \\
\hline
\end{tabular}

(Index, 1989=100)

Sources: National statistical publications and statistical office communications to ECE

Table 6: Real Gross Domestic Product, 1990-1995

\begin{tabular}{|l|c|c|c|c|c|c|}
\hline \multicolumn{1}{|c|}{ Country } & $\mathbf{1 9 9 0}$ & $\mathbf{1 9 9 1}$ & $\mathbf{1 9 9 2}$ & $\mathbf{1 9 9 3}$ & $\mathbf{1 9 9 4}$ & $\begin{array}{c}\mathbf{1 9 9 5} \\
\text { (half) }\end{array}$ \\
\hline Azerbaijan & -5.5 & -0.7 & -22.6 & -23.1 & -22.0 & -17.1 \\
\hline Kazakhstan & -1.0 & -11.7 & -13.0 & -12.9 & -25.1 & -18.5 \\
\hline $\begin{array}{l}\text { The Kyrgyz } \\
\text { Republic }\end{array}$ & 4.8 & -4.2 & -16.4 & -16.4 & -25.0 & -8.9 \\
\hline Uzbekistan & -0.7 & -0.5 & -11.1 & -2.4 & -4.0 & -2.0 \\
\hline
\end{tabular}

(Percentage change over preceding year)

Sources: National statistical publications and statistical office communications to ECE 
Table 7: Gross Industrial Output, 1990-1995

\begin{tabular}{|l|c|c|c|c|c|c|}
\hline Country & $\mathbf{1 9 9 0}$ & $\mathbf{1 9 9 1}$ & $\mathbf{1 9 9 2}$ & $\mathbf{1 9 9 3}$ & $\mathbf{1 9 9 4}$ & $\begin{array}{c}\mathbf{1 9 9 5} \\
\text { (half) }\end{array}$ \\
\hline Azerbaijan & 93.7 & 98.2 & 74.9 & 69.7 & 52.4 & 38.3 \\
\hline Kazakhstan & 99.2 & 98.3 & 84.7 & 72.3 & 51.7 & 43.5 \\
\hline $\begin{array}{l}\text { The } \\
\text { Kyrgyz } \\
\text { Republic }\end{array}$ & 99.4 & 99.1 & 73.0 & 54.5 & 38.3 & 31.7 \\
\hline Uzbekistan & 101.8 & 103.3 & 96.4 & 89.7 & 96.0 & 85.0 \\
\hline
\end{tabular}

(Index, 1989=100)

Source: ECE common data-base

Table 8: Changes in Gross Industrial Output, 1990-1995

\begin{tabular}{|l|c|c|c|c|c|c|}
\hline \multicolumn{1}{|c|}{ Country } & $\mathbf{1 9 9 0}$ & $\mathbf{1 9 9 1}$ & $\mathbf{1 9 9 2}$ & $\mathbf{1 9 9 3}$ & $\mathbf{1 9 9 4}$ & $\mathbf{1 9 9 5}$ \\
\hline Azerbaijan & -6.3 & 4.8 & -23.7 & -6.9 & -24.8 & -26.9 \\
\hline Kazakhstan & -0.8 & -0.9 & -13.8 & -14.6 & -28.5 & -15.9 \\
\hline $\begin{array}{l}\text { The } \\
\text { Kyrgyz } \\
\text { Republic }\end{array}$ & -0.6 & -0.3 & -26.3 & -25.3 & -29.7 & -17.2 \\
\hline Uzbekistan & 1.8 & 1.5 & -6.7 & -7.0 & 7.0 & -11.5 \\
\hline
\end{tabular}

(Percentage change over preceding year)

Source: ECE common data-base 